\title{
Studies on Drought Climatology of Different Districts of Chhattisgarh in the Backdrop of Climate Change
}

\author{
Yogesh Mahesh ${ }^{1}$, A.S.R.A.S. Sastri ${ }^{1}$, S.K. Chandrawanshi ${ }^{2 *}$, Pandurang Bobade ${ }^{1}$, \\ Hemant Kumar Bhuarya ${ }^{1}$, Pritpal Singh $^{1}$ and Deepak K. Kaushik ${ }^{1}$ \\ ${ }^{1}$ Department of Agrometeorology, Collage of Agriculture, Indira Gandhi Krashi \\ Vishwavidhyalaya, Raipur-4912 012, India \\ ${ }^{2}$ Agricultural Meteorological Cell, Department of Agricultural Engineering Navsari \\ Agriculture University, Navsari-396 450, Gujarat, India \\ *Corresponding author
}

\section{A B S T R A C T}

\begin{tabular}{|l|}
\hline K e y w o r d s \\
$\begin{array}{l}\text { Drought, Global } \\
\text { warming and } \\
\text { climate change }\end{array}$ \\
\hline Article Info \\
\hline $\begin{array}{l}\text { Accepted: } \\
\text { 04 October } 2018 \\
\text { Available Online: } \\
10 \text { November } 2018\end{array}$ \\
\hline
\end{tabular}

The present study Studies on drought climatology in different districts of Chhattisgarh in the back drop of climate change is carried out to study the drought climatology in different districts. It was found that though the mild drought intensity is less in Mahasamund, Dhamtari and Raigarh districts, the total number of drought years including mild, large, severe and disastrous droughts is more in these districts indicating that these three districts are more drought-prone. On the other hand Bilaspur and Janjgir districts are less drought prone when compared to other districts. The drought pattern in the back drop of climate change due to global warming was examined. It is very clear from the analysis that the number drought years in a 40 years period had drastically increased during post global warming period (1971-2010) as compared to pre global warming period. This a clear evidence of the impact of regional climate changes due to global warming on the rainfall pattern in all the districts of Chhattisgarh state.

\section{Introduction}

Agriculture provides the principal means of livelihood for over $58.4 \%$ of India's population. It contributes approximately onefifth of total gross domestic product (GDP). Agriculture accounts for about 10 per cent of the total export earnings and provides raw material to a large number of industries. Low and volatile growth rates and the recent escalation of agrarian crisis in several parts of the country are the major concern for the country. Aberrant weather is a part of agriculture in India affecting its production Only 20 per cent of cultivated land is irrigated. Drought and floods are the result of this aberrant weather making agriculture one of the weather sensitive industries. Floods, cyclones and storms have their adverse potential in a decreasing order of magnitude in view of limited area of occurrence. But, drought is extensive and prolonged when it occurs. As a result drought is considered as one of the biggest menace to agriculture among all weather related crisis. Unlike floods, drought has a creeping effect with an origin, spread 
and decay. Droughts leave tell- tale stories for a longer period on the lives of poor farmers. Rathore (2005) mentioned that the concept of drought varies from place to place depending upon normal climatic conditions, available water resources, agricultural practices and the various socio-economic activities of a region. The National Commission on Agriculture (NCA, 1976) in India defined three types of droughts, namely meteorological, agricultural and hydrological droughts. Agriculture drought occurs when soil moisture and rainfall are inadequate during the growing season to support healthy crop growth to maturity and causes crop stress and wilting. Bandopadhyay (1988) argues that various forms of droughts get generated independently but are inseparable and are linked to each other through the water cycle.

Palmer (1965) reported that agricultural drought is probably the most important aspect of drought, but that problem is more specialized and complicated than some investigators seem to realize. Sastri et al., (2002) Carried drought analysis and its impact on rice productivity in Chhattisgarh for the period of 1997-2002. They concluded that in the years 2000 and 2002 there was early season drought because of this beushening operation could not be done. Das et al., (2002) evaluated agricultural drought for dryland crops, using the weather data of 40 years i.e., from 1951-1990. Water balance was computed by using Thornthwaite water balance equation and evapotranspiration by Penman's modified method. They concluded that when the drought condition occurred during different phenological stages of the crop, the method used (moisture deficit index) assist farmers to make critical management decisions. Sarkar, (2000) studied agricultural drought of 1987 monsoon season in India by using Thornthwaite's weekly water balance technique. The results revealed that a major portion of the Gujarat state had continuously been under the grip of moderate to severe drought conditions since 18-24 June till September end. Other areas substantially affected were Rajasthan, Punjab. Haryana, coastal Andhra Pradesh, Madhya Pradesh, Uttar Pradesh and Vidarbha where prolonged drought spell abating only for short periods in the season. Srivastava et al., (2000) studied the drought and rice productivity in Chhattisgarh state especially for Raipur, Durg and Rajnandgaon districts. Drought frequency based on aridity index for few stations of Raipur districts and for different decades was worked out and found that mild to moderate droughts were more frequent in the region. For obtaining a clear impact of drought intensity on rice productivity, trends of rice productivity during normal as well as severe drought years at Raipur were worked out. It was concluded that productivity under both the situations showed increasing trend over the study period which was mainly attributed to improved technology.

On the basis of regional topography Chhattisgarh region is divided into three agroclimatic zones viz., (1) Chhattisgarh plains, (2) Bastar plateau and (3) Northern Hills. The general climate of the state is dry sub-humid type. The average annual rainfall is about $1400 \mathrm{~mm}$, which is largely contributed by South-West monsoon (about $90 \%$ rainfall during the period from June- Sep.). In rainfed agriculture drought or water stress at different growth stages is one of the major constraints. For assessing the suitability of different crops in a given region knowledge of the occurrence of water stress and the corresponding impact on yield is of paramount importance. For assessing the agricultural drought Baghel and Sastri (1992) proposed a new method of agricultural drought classification but it was for Indian arid zone. For assessment of drought climatology, the historical rainfall data is necessary. Using the annual rainfall data, the drought intensity is classified as 
mild, large, severe and disastrous. Based on this information drought climatology of a given region is assessed.

In Chhattisgarh state rice is the predominant crop grown under rainfed conditions. Farmers broadcast the seeds immediately after the onset of monsoon in a pre- ploughed field. They usually take long duration (more than 140 days) varieties, which flower in midOctober and mature by mid - November while South- west monsoon withdraws by mid September. Hence terminal drought is a recurring feature for rice crop in this area.

Also due to intermittent dry spells water stress conditions occur at different growth stages during crop growth period. In view of this, analysis of drought at different growth stages and its impact on rice productivity was carried out for four districts viz. Raipur, Bilaspur, Jagdalpur and Ambikapur districts.

Also in recent years climate change is a burning issue all over the world. The global warming period was considered from 1970 onwards. Hence the drought pattern during pre (1931-1970) and post (1971-2010) global warming periods was also studied.

\section{Materials and Methods}

\section{Data base}

\section{Rainfall data}

District wise annual rainfall data for the period 1901-2010 and weekly rainfall data for the period of 2001-2010 for Chhattisgarh state were obtained from the Department of Agricultural Meteorology, IGKV, Raipur.

\section{Rainfall departure (\%)}

The percentage rainfall departures from the normal values have been worked as follows
Departure $\%=\frac{\mathrm{X}-\overline{\mathrm{X}}}{\overline{\mathrm{X}}}$

Where,

$\mathrm{X}=$ Rainfall in a given year

$\overline{\mathrm{X}}=$ Mean of the data base

\section{Meteorological drought}

Using the rainfall departures, the different categories of drought have been categorised for different years in different districts using the following criterion-

\section{Weekly weather data}

The mean weekly weather data like maximum and minimum temperature, relative humidity, wind speed and sunshine hour required for the computation of Penman's potential evapotranspiration for the period of 2001 to 2010 for Raipur, Bilaspur, Ambikapur and Jagdalpur districts were obtained from the Department of Agricultural Meteorology, IGKV, Raipur.

\section{Potential evapotranspiration}

The weekly potential evapotranspiration for 4 districts for the period 2001-2010 was computed using the following formula of Penman's modified equation.

$\mathrm{E}_{0}=\frac{\Delta \mathrm{Q}_{\mathrm{n}}+{ }_{\gamma} \mathrm{E}_{\mathrm{a}}}{\Delta+{ }_{\gamma}}$

Where,

$\mathrm{Q}_{\mathrm{n}}=$ Net radiation in $\mathrm{mm}$ of water

$\mathrm{Q}_{\mathrm{n}}=\mathrm{Q}_{\mathrm{A}}(1-\mathrm{r})(0.18+0.55 \mathrm{n} / \mathrm{N})-\sigma \mathrm{Ta} 4(0.55-$

$0.092 \sqrt{ } \mathrm{ed})(0.10+0.90 \mathrm{n} / \mathrm{N})+\quad 0.35($ ea-ed $)$

$\left(1+\mathrm{U}_{2} / 100\right)$ 
Where,

$\mathrm{Q}=$ Extra- terrestrial radiation

$\mathrm{R}=$ albedo

$\mathrm{n}=$ actual sunshine hour

$\mathrm{N}=$ possible sunshine hour

$\sigma=$ Stephan Boltzmann constant

$\mathrm{Ta}=$ air temperature $\left({ }^{\circ} \mathrm{c}\right)$

ea $=$ saturated vapour pressure

ed $=$ actual vapor pressure

$\mathrm{U}_{2}=$ wind speed at 2 meter height

\section{Climatic water balance}

The climatic water balance for different stations and for different years was computed using the book-keeping procedure of Thornthwaite and Mather (1955). In the water balance computations, the inputs are rainfall and potential evapotranspiration (PET) and the outputs are soil moisture storage, actual evapotranspiration, water surplus and water deficit. The potential evapotranspiration values required for the water balance computations were estimated using modified Penman's equation.

\section{Software}

The modified Penman's potential evapotranspiration and climatic water balance using the book- keeping procedure of Thornthwaite and Mather (1955) were computed using the software WATBAL provided by CRIDA, Hyderabad. Besides the weather input the latitude and longitude of the 4 station are also needed for computation of PET in the software. They were given as input from the Table 1.

\section{Results and Discussion}

\section{Drought climatology}

The analysis was carried out to examine the drought pattern in different districts of
Chhattisgarh for period of 110 years and the trends of different intensities of drought before after the global warming period was also analyzed. Beside this the impact of drought / water stress on rice productivity was also analyzed. The results are as follows.

\section{Climatological drought}

It can be seen from Table 2 that the intensity of mild drought years were more when compared to large, severe and disastrous droughts. The number of mild drought years varied from 25 to 44 . The lowest number of mild drought years were observed at Mahasamund (25 years) followed by Durg (28 years) in 110 years. The highest numbers of mild drought years were observed at Bilaspur (44 years) followed by Bijapur district. This indicates that water stress was with low intensity in Bilaspur and Bijapur districts.

There is a lot of spatial variability in number of large drought years as compared to mild drought years. The number of large drought years ranged from 11 to 21 . The lowest number of large drought years was observed at Dantewada and Mahasamund districts (11 year) followed by Bastar and Narayanpur districts (12 years both). The highest number of large drought years was observed at Kawardha (21 years) followed by Dhamtari (20 years). This indicates that out of the 16 districts Mahasamund and Dhamtari districts are more drought-prone. The numbers of severe drought years were less compared to large drought years. The number of severe drought years ranged from 0 to 11 . The lowest number of severe drought year was observed at Janjgir (0 year) followed by Bilaspur (1 year). The highest number of severe drought year was observed at Mahasamund district (11 years) followed by Dhamtari and Raigarh districts ( 8 years both). This indicates that the Mahasamund, Dhamtari districts are more drought-prone when compared to other 
districts while Bilaspur and Janjgir districts are less drought-prone. Similar result was found Srivastasva et al., (2000)

As obvious the numbers of disastrous drought years were very less as compared to mild, large and severe drought years in different districts of Chhattisgarh state. The number of disastrous drought years varied from 0 to 6 . In Bastar, Bilaspur, Dantewada, Dhamtari, Raipur, Kawardha, Janjgir, Dhamtari, Bijapur and Narayanpur districts there was no disastrous drought in the 110 years. In Rajnandgaon, Korba, Koriya and Dantewada there was one disastrous drought year in 110 years. But the years are different. In Koriya districts it occurred in 1955, while in Korba district it occurred in 1959. In Raigarh district is occurred in 1996 and in Rajnandgaon and Surguja districts it occurred in 1974 and 2000 respectively. But it is very interesting to see that at Mahasamund district the disastrous drought occurred in 6 years and all of them are after 1980s. Total numbers of drought years under different categories are worked out and are shown in Table 2. It is clear from the table that total number of drought years were highest in Rajnandgaon district followed by Raipur (63) and Bilaspur and Kawardha districts (62 each).

\section{Meteorological drought}

\begin{tabular}{|c|c|}
\hline Rainfall departure & Drought severity \\
\hline 0 to -19.9 & Mild* \\
\hline-20 to -39.9 & Large \\
\hline-40 to -59.9 & Severe \\
\hline$\leq 60.0$ & Disastrous \\
\hline
\end{tabular}

(* for rain fed rice crop even a departure from normal values creates water stress conditions and hence it is categorized as mild drought

Table.1 Geographical locations of 16 districts of Chhattisgarh state

\begin{tabular}{|c|c|c|c|}
\hline S. No. & Station & Latitude & Longitude \\
\hline 1 & Bastar & $19^{\circ} 05^{\prime} \mathrm{N}$ & $82^{\circ} 02^{\prime} \mathrm{E}$ \\
\hline 2 & Bilaspur & $22^{\circ} 05^{\prime} \mathrm{N}$ & $82^{\circ} 08^{\prime} \mathrm{E}$ \\
\hline 3 & Dantewada & $18^{\circ} 53^{\prime} \mathrm{N}$ & $81^{\circ} 21^{\prime} \mathrm{E}$ \\
\hline 4 & Dhamtari & $20^{\circ} 42^{\prime} \mathrm{N}$ & $81^{\circ} 34^{\prime} \mathrm{E}$ \\
\hline 5 & Durg & 21013' N & 81017'E \\
\hline 6 & Janjgir & $22^{\circ} 01^{\prime} \mathrm{N}$ & $82^{\circ} 35^{\prime} \mathrm{E}$ \\
\hline 7 & Korba & $22^{\circ} 00^{\prime} \mathrm{N}$ & $82^{\circ} 42^{\prime} \mathrm{E}$ \\
\hline 8 & Koriya & $23^{\circ} 15^{\prime} N$ & $82^{\circ} 34^{\prime} \mathbf{E}$ \\
\hline 9 & Kawardha & $22^{\circ} 01^{\prime} \mathrm{N}$ & $81^{\circ} 15^{\prime} \mathrm{E}$ \\
\hline 10 & Mahasamund & $21^{\circ} 06^{\prime} \mathrm{N}$ & $82^{\circ} 06^{\prime}$ E \\
\hline 11 & Raigarh & $21^{\circ} 55^{\prime} \mathrm{N}$ & $83^{\circ} 24^{\prime} \mathrm{E}$ \\
\hline 12 & Raipur & $21^{\circ} 14^{\prime} \mathrm{N}$ & $81^{\circ} 39^{\prime} \mathrm{E}$ \\
\hline 13 & Rajnandgaon & $21^{\circ} 05^{\prime} \mathrm{N}$ & $81^{\circ} 02^{\prime} \mathrm{E}$ \\
\hline 14 & Surguja & $23^{\circ} 07^{\prime} \mathrm{N}$ & $83^{\circ} 12^{\prime} \mathrm{E}$ \\
\hline 15 & Bijapur & $18^{\circ} 50^{\prime} \mathrm{N}$ & $80^{\circ} 50^{\prime} \mathrm{E}$ \\
\hline 16 & Narayanpur & $22^{\circ} 29^{\prime} \mathrm{N}$ & $88^{\circ} 34^{\prime}$ E \\
\hline
\end{tabular}


Table.2 Climatological drought of different intensities in different districts of Chhattisgarh state (Data base: 1901-2010)

\begin{tabular}{|c|c|c|c|c|c|}
\hline Districts & Mild Drought & Large Drought & Severe Drought & Disastrous Drought & Total drought \\
\hline Bastar (1910-2010) & 40 & 12 & 2 & 0 & 54 \\
\hline Bilaspur (1901-2010) & 44 & 17 & 1 & 0 & 62 \\
\hline Dantewada (1903-2010) & 41 & 11 & 7 & 0 & 59 \\
\hline Dhamtari (1901-2010) & 30 & 20 & 8 & 0 & 58 \\
\hline Durg (1901-2010) & 28 & 18 & 6 & 1 & 53 \\
\hline Janjgir (1901-2010) & 36 & 17 & 0 & 0 & 53 \\
\hline Korba (1901-2010) & 37 & 14 & 5 & 1 & 57 \\
\hline Koriya (1913-2010) & 34 & 17 & 3 & 1 & 55 \\
\hline Kawardha (1902-2010) & 39 & 21 & 2 & 0 & 62 \\
\hline Mahasamund (1906-2010) & 25 & 11 & 11 & 6 & 53 \\
\hline Raigarh (1901-2010) & 31 & 16 & 8 & 1 & 56 \\
\hline Raipur (1901-2010) & 41 & 19 & 3 & 0 & 63 \\
\hline Rajnandgaon (1902-2010) & 40 & 19 & 6 & 1 & 66 \\
\hline Surguja (1901-2010) & 33 & 18 & 4 & 1 & 56 \\
\hline Bijapur (1903-2010) & 42 & 16 & 2 & 0 & 60 \\
\hline Narayanpur (1903-2010) & 40 & 12 & 6 & 0 & 58 \\
\hline
\end{tabular}


Fig.1 Climatological drought of different intensities in different districts of Chhattisgarh (Data base: 1901-2010)

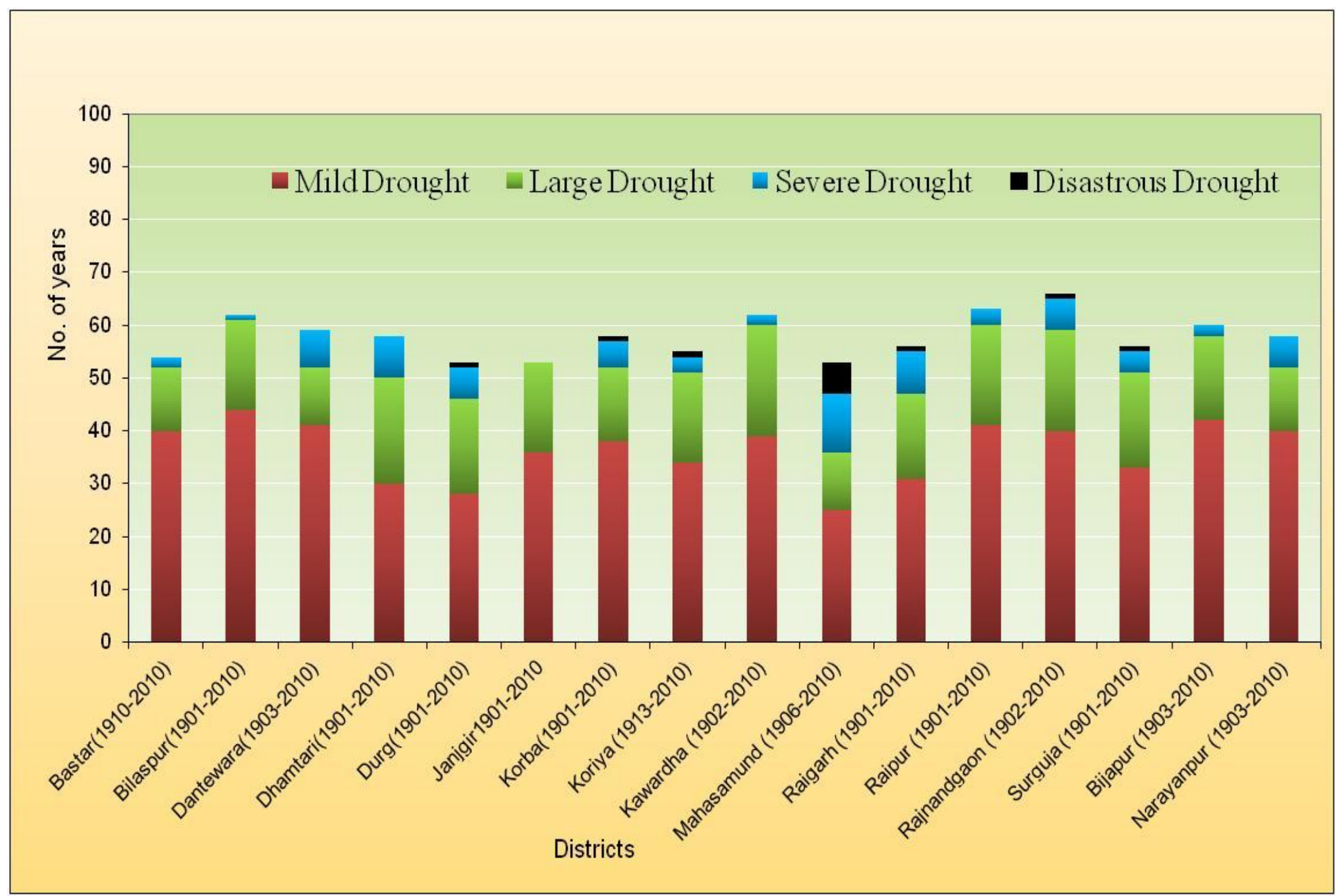


It can also be seen from table that the total number of climatological drought years varied from 53 to 66 years. The lowest number of total climatological drought years were observed at Durg, Janjgir, and Mahasamund (53 years each) followed by Bastar, Koriya (54 years both) and Raigarh (56 years) districts. The highest number of climatological drought years were observed at Rajnandgaon (66 years) followed by Raipur (33 years). In remaining districts the total number of climatologically drought years ranged between 54-62 years, shows in figure 1, Sastri, (2006) was reported agricultural drought: Concepts, assessment and management in Chhattisgarh.

In Chhattisgarh state in eastern India more than 80 per cent of the population is dependent on agriculture for their livelihood. Chhattisgarh state stretches between $80^{\circ} 15^{\prime}$ to $84^{\circ} 24^{\prime} \mathrm{E}$ longitude \& $17^{\circ} 46^{\prime}$ to $24^{\circ} 5^{\prime} \mathrm{N}$ latitude. It covers total area of about 13.5 million hectare. At present the state has 27 districts. But the historical meteorological data is available for only 16 districts. Hence, the analysis of drought climatology of 16 districts of Chhattisgarh for the period of 1901 to 2010 was carried.

Thus, the rice cultivation in Chhattisgarh had become risky under rainfed conditions and therefore the government is recommending crop diversification in these unproductive areas.

Based on the studies of drought climatology of different districts of Chhattisgarh the drought pattern was studied. The number of mild drought years in all the districts varied from 25 to 44 . The lowest number of mild drought years was observed in Mahasamund district (25 years) followed by Durg district (28 years) in 110 years. The highest numbers of mild drought years were observed in Bilaspur district (44 years) followed by
Bijapur district (42 years). The number of large drought years ranged from 11 to 21 years in different districts. The lowest number of large drought condition is observed at Dantewada and Mahasamund districts (11 years both) followed by Bastar and Narayanpur districts (12 years). The number of severe drought years ranged from 0 to 11 years with lowest at Janjgir (0) and highest at Mahasamund districts (11 years).

It is found that the total numbers of drought years increased significantly in all the districts during post global warming period. In Mahasamund district during the pre-global warming period (1931-1970) the drought years were 4 years while in the post global warming period (1971-2010) there were 24 years. Similarly in Raigarh district during the pre-global warming period there is only 1 drought year in 40 years while in post global warming period there were 22 drought years. It was found that Mahasamund Dhamtari and Raigarh districts suffered from frequent droughts during the post global warming period. Bastar district had least number of drought years even during the post global warming period. The other districts which suffered from drought in the post global warming period are Rajnandgaon, Durg and Surguja districts followed by Raipur, Koriya and Kawardha districts.

\section{References}

Baghel, S. S. and Sastri, A. S. R. A. S., 1992. Regional climate change and its influence on agriculture - A case study for Chhattisgarh region of Madhya Pradesh, First Agricultural Science Congress, 213-222.

Bandopadhya, J., 1988. Water scarcity by choice. Seminar, 346: 24-27.

Das, H. P., Geonkar, S. B., E. I. and Pandey, V.K., 2002. Evaluation of agricultural 
drought for dryland crop. Mausam. 53, 3: 375-380.

Palmer, W.C. (1965). Meteorological drought Research paper no.45, Washington D.C.: Office of climatology, U. S. Weather Bureau.

Rathore, M. S., 2005. State level analysis of drought policies and impacts in Rajasthan India, Colombo, Srilanka. Working paper 93, Srilanka: International Water Management Institute.

Sarkar, J., 2000. Agricultural droughts of 1987 monsoon season in India, Journal of Agrometeorology, 2, 1: 55-60.

Sastri, A.S.R.A.S., 2006. Agricultural drought: Concepts, assessment and management Director of Research $I G A U$, Raipur (C.G.), Central Research Institute for Dryland Agriculture, Hyderabad, India.

Sastri, A.S.R.A.S., Rao Hemasundar G., Naidu, D. and Yadav, S., 2002. Project report on drought analysis and its impact on rice productivity in Chhattisgarh, IGAU, Raipur, pp 7-8.

Srivastasva, A. K., Sastri, A.S.R.A.S. and Naidu, D., 2000. A note on drought and rice productivity in Chhattisgarh state, Journal of Agrometeorology, 2, 1, 7581.

Thornthwaite, C. W. and Mather, J. R., 1955. The water balance Laboratory of Climatology", No. 8, Centerton N. J.

\section{How to cite this article:}

Yogesh Mahesh, A.S.R.A.S. Sastri, S.K. Chandrawanshi, Pandurang Bobade, Hemant Kumar Bhuarya, Pritpal Singh and Deepak K. Kaushik. 2018. Studies on Drought Climatology of Different Districts of Chhattisgarh in the Backdrop of Climate Change. Int.J.Curr.Microbiol.App.Sci. 7(11): 252-260. doi: https://doi.org/10.20546/ijcmas.2018.711.031 